VIII-1 | 2016

Dewey's Democracy and Education as a Source of and a Resource for European Educational Theory and Practice

\title{
The Many Lives of John Dewey's Democracy and Education
}

A Historical Account of the Reception of a Book Still to Be Read

Samuel Renier

\section{CpenEdition}

1 Journals

Electronic version

URL: https://journals.openedition.org/ejpap/448

DOI: $10.4000 /$ ejpap.448

ISSN: 2036-4091

\section{Publisher}

Associazione Pragma

Electronic reference

Samuel Renier, "The Many Lives of John Dewey's Democracy and Education", European Journal of Pragmatism and American Philosophy [Online], VIII-1 | 2016, Online since 20 July 2016, connection on 21 September 2021. URL: http://journals.openedition.org/ejpap/448; DOI: https://doi.org/10.4000/ ejpap.448

This text was automatically generated on 21 September 2021.

\section{$\Theta \Theta \Theta$}

Author retains copyright and grants the European Journal of Pragmatism and American Philosophy right of first publication with the work simultaneously licensed under a Creative Commons AttributionNonCommercial-NoDerivatives 4.0 International License. 


\title{
The Many Lives of John Dewey's Democracy and Education
}

\author{
A Historical Account of the Reception of a Book Still to Be Read
}

\author{
Samuel Renier
}

1 A century ago, the American pragmatist philosopher John Dewey published one of his major and most influential books with Democracy and Education. After one hundred years, it should be noted that this book has been regularly reprinted and translated in numerous languages, ensuring the dissemination of its ideas in a diversity of countries and cultural contexts. The question it immediately raises concerns the topicality of the ideas presented in a book written in quite a different social background. How can Democracy and Education still be considered as a relevant book for today, and for today's issues in a variety of social conditions that necessarily could not be foreseen at the time of its primal publication? Apart from an a priori answer which would simply postulate the timeless content of the ideas expressed in this particular book, it leaves us with the question of its reception, that is to say of the uses which were made of it and which conferred to it an actuality as well as a particular interpretation. In this respect, the case of the French reception of Democracy and Education appears to be especially interesting insofar as the century which separates us from Dewey's original edition doesn't present itself as a steady and equal movement of diffusion, as it wasn't translated into French until 1975, thanks to the efforts of Gérard Deledalle.

2 Over the last decade, the reception of Deweyan thought in France has begun to be studied from a historical and philosophical point of view. Two trends may be distinguished within this field of study. On the one hand, extensive studies of the reception of pragmatism as a whole, that is to say as a philosophical movement, encompassing all its major figures, including Dewey. In so doing, they try to picture a global portrait of the encounter of two different philosophical cultures (Pudal 2007; Schultenover 2009). On the other hand, we find an increasing number of limited studies focusing on the reception of Dewey's sole educational ideas, especially within the New Education movement and its leaders (Schneider 2000; Renier 2012; Renier 2013; and Frelat-Kahn 2013). These two types of 
studies do reveal themselves very useful in order to understand how a book like Democracy and Education has progressively found its way into the French intellectual background. However, as "an introduction to philosophy of education," this book stands in between these two trends. It establishes a third way according to which "philosophy of education" is neither the field of application of some general philosophy nor a particular outlook on the educational phenomena. It rather develops a comprehensive view on our everyday experience of learning and growing in a world constantly evolving, calling for a new definition of philosophy and philosophical practices.

On the basis of this observation, we may not consider the reception of Democracy and Education with predetermined categories of analysis, which would lead us to endless oppositions. From a methodological standpoint, we may take as a working hypothesis that the definition of the ideas expressed in Democracy and Education are the result of a transaction between the book and its readers. There is no definite truth about it but only a multiple way to produce operational significations on its basis. There isn't, equally, bad, wrong, inadequate or insufficient interpretations of Dewey's ideas. What we shall try to establish is that there is, each time, a process of appropriation which has to be understood and assessed relatively to the situation and the project of the person or group of persons making use of Dewey's Democracy and Education. From this attention to the singular meanings given to it, we shall then attempt to better understand the plural character of Dewey's book and the sense which may be attributed to his project of introducing a philosophy of education.

Though focusing on the reception of Democracy and Education cannot be totally realized without a consideration for the rest of his works, sometimes taken as a whole by its readers, it is possible to identify two major moments within the one hundred years of Dewey's presence in France. These moments do correspond to two historical phases of the reception of Democracy and Education: firstly, the years surrounding its primal edition in the United States, at the beginning of the 1920s, during which a first wave of diffusion resulted from the reviews published in French journals; secondly, the years following the French translation issued by Deledalle in 1975, sixty years after its original publication. Taking reviews as our main material does not mean that other ways of diffusion of the views expressed in Democracy and Education didn't existed or that their influence was of lower importance. But it shall humbly put the emphasis on the visibility given to it in some journals and by the action of specific individuals picturing a certain image of Dewey. Like ferrymen, or sometimes smugglers, their contribution is to pass this book through national, cultural and even historical frontiers and they help us to better understand the frontiers which Dewey might help us pass today.

\section{Introducing Democracy and Education: (1917-1927)}

Published in 1916 in the United States, Democracy and Education first arrived in France through the reviews published in several journals. These early appraisals of Dewey's book, despite their reduced number, offer us a plural vision of its reception. Either focusing on a sociological, a philosophical or a pedagogical standpoint, these interpretations are worth studying insofar as they contribute to giving distinct and divergent orientations to Dewey's reflection to the French audience. 


\subsection{A Sociological Standpoint on Education in a Democracy}

6 In June 1920, the Bulletin de l'Association Française pour la Lutte contre le Chômage et pour l'Organisation du Marché du Travail (Bulletin of the French Association for the Struggle against Unemployment and for the Organization of the Job Market) dedicated a whole issue to the topic of "Education and Vocational Guidance." Among the four articles presented in this issue, John Dewey's Democracy and Education is granted a prominent place, with a full translation of its twenty-third chapter on "Vocational Aspects of Education," and a large review written by Max Lazard. ${ }^{1}$ They are accompanied by a long introduction of Julien Fontègne ${ }^{2}$ on the current development and the present need of vocational guidance, and followed by a detailed international bibliography established by Fontègne on the subject. But why is Democracy and Education given such importance and what is the purpose of the editors, Lazard and Fontègne, in doing so?

One may note that the choice of the 23rd chapter of Dewey's book is no coincidence. Vocational education represents at that time a burning issue around which Fontègne and Lazard worked heavily. The aftermath of World War I and the persistence of a traditional school system gave no place to the emergence of vocations. Either pupils having to decide on their future or adults, disabled veterans especially, having to choose a different course for their lives and activities faced the same problem: the organization of the course of study and of the social setting of the job market can't help them much. As a consequence, the issue of "course choice" (orientation) soon became a real issue. How to define and classify a profession among others? What are the requirements to practice it? Can we determine psychological types which may help to organize the choices made by individuals or suggested to them? All these questions prove to be central, as Fontègne points out in his study, and meet Dewey's own reflections.

8 This community of views is all the more stressed in Lazard's review as he provides an interpretation of Democracy and Education in which educational and pedagogical thinking are less important than the role that education plays in organizing society. The definition, given by Lazard, of education in Dewey's book is strangely similar to the sociological one given by Durkheim:" "By education, society seeks to deliver to young generations the skills which are necessary to the conservation of the social habits of acting, of thinking, of feeling" (Lazard 1920: 28). Dewey's definition of philosophy, as "the general theory of education," is consequently to be understood as an organized interpretation of the social settings surrounding education in a given society. In so doing, Lazard diverges greatly from antecedent interpretations of Dewey's educational philosophy which were developed in France (Renier 2013).

Another review, much shorter than the precedent one, of Democracy and Education blatantly illustrates the divergence of views between Lazard and Fontègne, on the one side, and the defenders of a pedagogical interpretation, on the other. Published in December 1917 by the journal L'éducation (Education), this review is signed by Albert Kohler. ${ }^{4}$ In a couple of pages, it presents Dewey's general orientations in his book, which he qualifies "a very considered and highly systematized pedagogical theory" (Kohler 1917: 453). Kohler particularly emphasizes the link between the social macrocosm and the school microcosm. If life is defined by its continuity, then education has to focus on the social significance of its matters through the alliance of theory and practice. These points are certainly to be found in Democracy and Education, but they also represent the core 
issues of The School and the Child, ${ }^{5}$ translated into French a few years before and highly praised by French educators (Renier 2013: 28-30). Quite the opposite, the interpretation defended by Fontègne and Lazard will remain totally unnoticed. Their translation of Democracy and Education's 23rd chapter is, as far as we know, never quoted in the papers analyzing Dewey's ideas and no references are ever made to it during the following years. ${ }^{6}$ Dewey's legacy, in their works, soon transforms itself and becomes that of theoretician of "activity" and of the role played by manual activities in the training of pupils (Fontègne 1923).

\subsection{French Philosophy and Dewey's Pragmatism}

10 The same year as Fontègne and Lazard, another review gave evidence of the great attention paid to Dewey's Democracy and Education. Published in the Revue philosophique de la France et de l'étranger (Philosophical Review of France and Abroad), it was written by the French philosopher André Lalande. ${ }^{7}$ In this text, Lalande performs a common review of Dewey's book with the one issued by Ludovic Zoretti ${ }^{8}$ entitled Éducation, un essai d'organisation démocratique (Education: an Attempt at Democratic Organization) in 1918. This choice made by Lalande to associate them in a common review is explained by the community of views they seem to share. Both try to indicate a way of reforming the educational school system in a more democratic way. But, as Lalande quickly points out, they do not develop the same kind of rationale. While Dewey presents "a serene philosophy of education [...] written by an optimist" (Lalande 1920: 278), Zoretti goes into an analysis of the French educational situation, marked off by the war and by the evolution of its institutions and the socio-economic global background since the Revolution. To materialize the use he makes of these two texts, Lalande starts by the review of Democracy and Education, before getting into Zoretti's book and finally making a comparison of them in which he tries to establish the signification of democracy as a process of organization of the social diversity of individuals into a political unity, that may arise from the common reading of these books.

11 Of all the reviews dedicated to Democracy and Education in the French context, the one written by Lalande stands out, for it certainly is the most extensive. In ten pages or so, he develops a comprehensive outlook on Dewey's conception, in which he identifies a fundamental and organizing principle, on the basis of which we should understand the philosophical development that he makes in his book. This principle is that of experience, defined as follows:

$[E] x p e r i e n c e$ implies the community of tested thoughts and of the control which verify them. The moral value of an institution can be measured by the degree of experience and, consequently, of inter-mental contact it brings about. (Lalande 1920: 279)

12 This explains the philosophical interest one is to find in education as a subject of study, as the main process of constitution of such experience. This also leads us to a renewed insight on pedagogy as far as education organized by experience distinguishes itself from mere drilling. As a consequence, it invites us to think anew the signification we give the democratic organization of society according to the place it allows to the experience of individuals as well as to the cooperation within and outside the political unity of nationstates. This, Lalande concludes, is the signification of "a pragmatist program," defined as “experimentalist" (Ibid.: 284). 

constitutes a genuine part of the philosophy he progressively develops at that time. In the famous edition of his Vocabulaire technique et critique de la philosophie (Technical and Critical Vocabulary of Philosophy), Lalande writes an article on "Pragmatism" which he defines as a full philosophical tradition. But it is noticeable that his understanding of it relies more on Peirce than on Dewey. While Peirce is quoted as giving the definition of the pragmatist principle - in his article "What Pragmatism Is" -, Dewey never appears in that entry but he is rather classified in another one, called "Instrumentalism" and defined as "a variety of pragmatism: the doctrine of M. John Dewey" (Lalande 2006: 520). Lalande then constantly refers to Peirce in preference to Dewey, developing his analysis of the process of "induction" (Lalande 1929). Even if he does never give an explanation of such a situation, it is possible to make the assumption that Lalande finds in Dewey a theory of experience, whereas he identifies in Peirce a theory of experimentation. The distinction might seem very slight and shall necessarily depend on the meaning attributed to these two concepts, but the review of Democracy and Education clearly shows that the focus on experience serves to describe the concrete relationship of man with the phenomena in which he composes his life, sometimes quite hazardously. Experimentation, as Lalande specifies in his vocabulary, is "a method which consists in having a series or a set of experiences" (Lalande 2006: 324), thus adding to it the idea of a conscious control developed systematically. While dedicating to him an extensive and interested review, Lalande will never thereafter make a use of Dewey's insights. ${ }^{9}$

\subsection{The New Education Movement and Its Pedagogical Outlook}

The third protagonist of the early reception of Democracy and Education in France is not French but Swiss, in the person of Adolphe Ferrière. Though Ferrière's review of Dewey's book appeared quite later - in 1927 - than the other ones, the interest of the former in the works of the latter may be found more than a decade earlier. As soon as 1914, Ferrière writes a letter to Dewey in which he acknowledges a form of admiration for his works and his ideas (Ferrière 2010). Having read the recent translation of The School and the Child, he mentions it as "the most important work [he] has ever read in the field of education" and considers "to share [with him] so completely a philosophical and pedagogical ideal." However, their direct relationships seem to limit themselves to these vague contacts. The edited correspondence of Dewey mentions no other letter from him or sent to him.

At the time of the publication of his review, Adolphe Ferrière is already a well-known leader of the New Education movement, which he contributed to at a European and global level. Having founded the International Bureau of New Schools ${ }^{10}$ in 1899, he took an active part in the foundation of the International League for New Education, ${ }^{11}$ and he was the director of the French version of the journal New Era, published under the title Pour l'ère nouvelle since 1922. The choice to publish his paper in another journal, L'éducation, reveals something of Ferrière's aim in reviewing Dewey's work. In comparison with Pour l'ère nouvelle, more focused on concrete educational initiatives, L'éducation is a journal where it is possible to publish large and detailed reflections, commentaries or reviews. ${ }^{12}$ Ferrière's outlook in this text covers both these fields of interest, insofar as he achieves a detailed exposition of Dewey's ideas throughout Democracy and Education, but at the same time he constantly stresses the concrete pedagogical side of these ideas. According to his words, Dewey's book is "less a systematical treatise than a class lecture" (Ferrière 1927:

European Journal of Pragmatism and American Philosophy, VIII-1 | 2016 
274). He sees in Dewey the promoter of an "active school and [of] a program based on child's fields of interests" which, he adds "are the same one idea" (Ibid.: 278). Indeed, "school is an obstacle to the fulfillment of the democratic ideal" (Ibid.: 275) and has consequently to be transformed. And, to conclude his demonstration: "So, and only so, man rises to freedom" (Ibid.: 279).

These quotes from Ferrière teach us two points. The first one is that he employs his own vocabulary to describe Dewey's thought. "Active school," "fields of interest," "transformation of the school," and "freedom in education" are elements of language we find in his works, such as L'école active (The Activity School), ${ }^{13}$ Transformons l'école (Transforming Schools) ${ }^{14}$ or La liberté à l'école active (Freedom in the Activity School). Here Ferrière explicitly attempts to show a convergence between Dewey's book and his own ideas. Ferrière was no philosopher and searched during his whole life a solid base to establish his educational theories (Hameline 1995). With Dewey, especially in Democracy and Education, he found a theory which may help him at a time of controversy on the sense of activity (Tröhler 2009: 74); a theory that presents itself under a philosophical form.

The second point is more practical and concerns the role that Ferrière played in the reception and the diffusion of Dewey's thought. Seen from a transactional angle, this movement of identification reveals a process of familiarization. ${ }^{15}$ Employing terms which are familiar to French educators, and focusing on the pedagogical consequences of the views presented in Democracy and Education, Ferrière contributes to lessen the strange, if alien, aspect of a foreign thought elaborated in a distant context.

The decade going from the original publication of Democracy and Education to the last review we mentioned by Adolphe Ferrière enables us to better understand the diversity of motives and interpretations behind the reception of Dewey's book in France. This reception doesn't naturally stop after this first moment but tends to become more discrete, due to the lack of a French translation. Meanwhile, other works of Dewey were published in France, with How We Think in 1925, Schools of Tomorrow in 1931, Experience and Education in 1947 or Freedom and Culture in 1955, along with a cyclical reprinting of The School and the Child. This specific configuration of the Deweyan thought will only start to change at the end of the 1960's with the action of a great Dewey scholar: Gérard Deledalle.

\section{Translating Democracy and Education: (1975-1978)}

Though considered as a major piece of philosophy on education by its first reviewers in France, Democracy and Education has not received much attention during the following decades. A French edition was finally published in 1975, thanks to the translation done by Gérard Deledalle. In a different context of reception, the question it now raises concerns the attention paid to a sixty-year old book, as well as its significance for a new generation of readers.

\subsection{Taking Pragmatism Seriously}

By the middle of the years 1960s, the situation of pragmatism in France has greatly evolved. The sociological movement which once found interest in pragmatism, and Dewey in particular, has now turned to a more specialized discipline, enrooting its social 
theories in practical inquiries, like Pierre Bourdieu and Jean-Claude Passeron's book on The Inheritors published in $1964 .{ }^{16}$ Philosophical reflection also renewed itself during that period. The prime interest for pragmatism vanished over the years, equally touching Dewey, James and Peirce (Girel 2014: 17). On the educational side, the situation is no better. If Dewey's reputation did not disappear and remained vivid, the New Education movement slowly came to an end after World War II. Its main figures, including Dewey, turned to be household names, associated with the past history of educational thinking and experiments (Renier 2013: 43-5). A few academic works do however balance this pessimistic picture with: the reprinting of Ou Tsuin-Chen's doctoral dissertation in 1958, on La doctrine pédagogique de John Dewey (John Dewey's Pedagogical Doctrine), and the successive presentation of Zoilla Bayley de Erminy, entitled John Dewey, éducateur: une théorie de l'expérience et de la liberté (John Dewey as an Educator: A Theory of Experience and Freedom) and of Dang Van Toan on L'éducation sociale d'après Platon et Dewey (Social Education According to Plato and Dewey) in 1965 before the Sorbonne. But these three works only had little impact insofar as their authors were all of foreign origin and did not stay long enough to develop their influence in France. Moreover, the last two were never published, apart from the volume presented for examination, and remained quite invisible for the French audience.

But that series will not be complete without another dissertation presented in 1967, still before the Sorbonne, by a French scholar named Gérard Deledalle, on L'idée d'expérience dans la philosophie de John Dewey (The Idea of Experience in John Dewey's Philosophy). In comparison with his predecessors, Deledalle's dissertation is neither solely nor primarily concerned with the educational aspect of Dewey's philosophy. However education does represent a subject of study, situated within the whole of Dewey's philosophy. This trend is visible in Deledalle's thesis as well as in the small book he wrote in 1965 on La pédagogie de John Dewey (John Dewey's Pedagogy), ${ }^{17}$ whose subtitle qualifies it as a "philosophy of continuity." Philosophy and pedagogy are not clearly distinct or, if they are, they are closely connected with each other. Within such a frame, Democracy and Education appears to be an important part of Dewey's general theory of education, which Deledalle quotes repeatedly.

Its importance becomes even more obvious with its translation, in 1975, by Deledalle himself. His translation of Democracy and Education confirms his interest in Dewey's philosophy of education. The French edition, published by Armand Colin, presents a full translation of the original American edition, preceded by an essay written by Deledalle, and without additional notes. ${ }^{18}$ Despite its shortness, this presentation appears to be of great importance, according to the background it sets to introduce Dewey's book. Deledalle insists on the subtitle of Dewey's book: Democracy and Education is an "introduction to the philosophy of education." As a treatise of philosophy of education, it is possible to grant it a triple destination. First of all, it may be read as "a treatise of pedagogy or educational sciences" or even "a textbook" (Deledalle 1975: 7). The philosophical interest of Dewey is that it does not confine itself to an empirical field but rather tries to reach the "principles" of education and to question them. It may so be useful to the professional educators as well as prospective students in the newly-created university discipline precisely called "Educational sciences." ${ }^{19}$ But, according to Deledalle, it may also be read as a book of philosophy of education, that is to say an extended reflection on education, as an integrated part of a philosophical whole, as Plato or Rousseau did. Taking education as a subject, Democracy and Education invites philosophers 
to think anew on their conceptions of society, of the individual and its behavior, etc., insofar as "[e]ducation is everyone's experience, of children as well as adults, including educators, at every moment of one's life, in every situations of work and play or leisure" (Deledalle 1975: 9). It may also and finally be read as a thorough insight on our current social and educational problems, in order to analyze them. The philosophical rationale developed by Dewey is thus to be understood as a response to the problems which he identified at his time. These problems, which emerged in a different context, are not totally alien to us and we may wonder if some of our own problems could benefit from the analysis offered by Dewey in Democracy and Education, about the effects of industrial development on individuals or social cohesion. Each of these three ways of reading Dewey's book indicates Deledalle's preoccupation of the philosophical value its readers may find in its pages.

The publication of Democracy and Education due to Gérard Deledalle is consequently to be linked with the more comprehensive view of Dewey and of pragmatism he developed in the same years. From this point of view, and without denying the great effort of translation he accomplished, Deledalle does not grant to it an extraordinary place or function within Dewey's production. Repeatedly insisting on the primary character of "continuity" in Dewey's philosophy, Democracy and Education does not represent a landmark but rather inserts itself in the continuity of Dewey's pedagogy, going from its first experiments at Chicago to its last essays around World War II. The new presentation Deledalle writes for the second printing of his translation in 1990 confirms this trend. Instead of presenting the book itself, it proposes a global apprehension of "John Dewey's pedagogy" (Deledalle 1990). This tendency is also and generally present throughout the works of Deledalle on Dewey and does not concern Democracy and Education alone. As existence itself, and the existence of man in its environment, the philosophy of Dewey is ruled by two major concepts: experience and continuity. ${ }^{20}$ On a more practical side, Deledalle's intellectual enterprise may also be considered as an effort to show and to demonstrate the fact that there is a genuine and consistent philosophy in Dewey's works, and that his philosophy deserves attention as far as it belongs to the philosophical tradition of pragmatism and, more generally, of American Philosophy (Deledalle 1954, 1987, 1995).

\subsection{Taking Education Out of Ideologies and Doctrines}

Democracy and Education was reviewed three times ${ }^{21}$ during the years following its first publication in French. Though this number might seem quite low, the reviews, and their reviewers, did play a great role in its reception as well as their reading of Dewey's book eventually had an enduring influence over their thinking.

Chronologically, the first review to be published appeared in the 186th issue of the journal La pensée (Thought), in April 1976, and was due to Georges Cogniot. ${ }^{22}$ In this text, Cogniot performs a collective review of Dewey's Democracy and Education, along with L'école primaire divise (Primary School do Divide) by Christian Baudelot and Roger Establet, and Les grands problèmes de l'éducation dans le monde (The Great Problems of Education in the World), written by Jean Thomas on behalf of the International Bureau of Education. Cogniot starts by acknowledging the perspicacity of Dewey's insight, when he states that modern societies do cultivate a separation of their citizens between different social classes, helped by a school system which enlarges the gap between them. But he quickly 
diverges then from Dewey's view concerning the ways of fighting this gap. According to him, Dewey completely misses his target in Democracy and Education, insofar as he grants education a mission it cannot fulfill. Pedagogy itself is no remedy to social troubles, and the schools are unable to reform the same society that conditions them. This "vicious circle" relies, Cogniot says, on a noble idea which is to develop the ability of men to think by themselves, helped by a greater continuity between the school and its social environment.

But here precisely relies the bone of contention. From the Marxist point of view defended by Cogniot schools can't cause a social reform; social change has to come first, in order to set proper conditions to develop a renewed education. That's why he considers Dewey to be "the perfect example of an idealistic thinker" (Cogniot 1976: 107) and Democracy and Education to "reek completely of a crazy idealism" (Ibid.: 108) or, even worse, "of total magic, of total pedagogistic utopia" (Ibid.: 108). ${ }^{23}$ The analysis delivered here by Cogniot is neither the first nor the only one to charge Dewey with such criticism in the French media. As early as 1953, he had already denounced "America's cheap intellectual rubbish, for instance the pedagogical junk of John Dewey" (Cogniot 1953: 6), along with Georges Snyders. ${ }^{24}$ Beyond the ideological character of the position assumed by Cogniot, his review of Democracy and Education does rise a series of questions concerning the status of philosophy of education, relatively to other philosophical and social issues, as well as the aim and function of educational thought or pedagogy.

The status of philosophy of education lies in the heart of the second review dedicated to the French translation of Democracy and Education. Written by Guy Avanzini, ${ }^{25}$ it was published in the 555th issue of the bulletin edited by the Societé Alfred Binet et Théodore Simon, in 1977. Differently from Cogniot, Avanzini does not put forward a militant speech but rather develops a scientific discourse on education. The journal itself represents this divergence of views, for it was created by Binet and Simon in their joint effort to promote a scientific study of education at the beginning of the 20th century. In a couple of pages only, Avanzini underlines the importance of Dewey's books for the New Education movement, of which "he represents the spirit" (Avanzini 1977: 101). This spirit does not imply that Dewey would be the champion of all the pedagogical initiatives that were gathered under this label, but that he deepens the comprehension of its "spirit." Instead of furnishing us a "method" just as did the "Méthodes actives," it aims at "preparing for liberal democracy" (Ibid.: 100).

This slight difference may seem anecdotal, but it points out the change Deledalle brought about with the translation of Democracy and Education. Dewey can no more be considered as a pioneer or a leader of the New Education movement because he does not completely belong to it nor share all the meanings that are expressed in its name. As a book of philosophy of education, it proposes a reflection which is distant from the realities and the diversity of pedagogical experiments. ${ }^{26}$ It may thus be read apart from the debates which concern this movement, either to endorse it or to devaluate it. That's why Avanzini stresses the "greatness and weaknesses" of the book, whatever "value judgment" we may attribute to it, ${ }^{27}$ because of its significance for today's educational issues. Philosophy of education, in this respect, represents a way of analyzing these issues and of taking some distance from them in order to think on the principles and the values they engage as well as the questions they raise. 


\subsection{Founding Philosophy of Education as a Genuine Subject of Study and Field of Research}

The third review of Democracy and Education was finally released in 1978, in the Revue de Métaphysique et de morale (Review of Metaphysics and Morals), by Olivier Reboul. ${ }^{28}$ Though this review was published almost three years after the release of Dewey's book, the author had a long-standing acquaintance with John Dewey's philosophy, and Democracy and Education in particular. He previously published a review of it, before it was translated into French, in the 279th issue of the journal Critique in $1970 .{ }^{29}$ His acquaintance is moreover no coincidence, if we consider the long-term friendship existing between Gérard Deledalle and him since their common time at the University of Tunis at the beginning of the years 1960s. ${ }^{30}$

Though being a specialist of the philosophy of Alain, about which he wrote his thesis dissertation, Reboul took great advantage of the reading of Dewey ${ }^{31}$ In his review, he goes through the same questions that Avanzini and, to a lesser extent, Cogniot pointed out. That is to say: the primacy of continuity in man's experience and its expression through education, and the necessity of a reorganization of the continuum between school and society (including the debate between Dewey's position and a Marxist one). But what differentiates Reboul from his immediate predecessors is the emphasis he puts on the epistemological change introduced by Dewey. "It was about time [to publish a French translation of Democracy and Education]," he states, "because, finally, we have a genuine treatise of philosophy of education" (Reboul 1978: 427). The phrase "philosophy of education" here designates, according to him, a real and distinct field of study. It is no new name for "the old general pedagogy" (pédagogie générale) nor "the geometrical center of every hare-brained idea" opposed to the objectivity of empirical researches on education. Developing philosophy of education signifies that concrete experience can be studied in relation to a more general reflection on the means and ends of education, so as to enrich and mutually define them anew. This is precisely the definition he gives of that discipline in his own seminal textbook, La philosophie de l'éducation (Philosophy of Education) published in 1971: "Philosophy of education so has a double specificity. Toward Educational sciences, because of the type of questions it raises. Toward other branches of philosophy, because of its object, education" (Reboul 2004: 15).

This enterprise of definition of a singular field of study will prove itself useful in the development of 'Philosophy of education' within the general field of the 'Educational sciences' (Renier forthcoming), but it also places Dewey and his Democracy and Education in a position of marginalization toward the general field of Philosophy.

Democracy and Education was not, at that time, received as a book of philosophy. It seems that the philosophers who were not directly or primarily concerned with educational issues and questions did not pay much attention to it. Deledalle's personal involvement did certainly play a role to reverse this situation. For instance, he invited Michel Foucault in Tunisia and had extended discussions with him over Dewey and his philosophy. Deledalle gave him his two dissertations to read and Foucault used heavily the books Deledalle had gathered on Dewey and American Philosophy. As he asserts, "The Archeology of Knowledge is of 'pragmatic' inspiration - 'pragmatic' neither in the sense of James nor of Peirce, but in the sense of the philosophers of ordinary language and of Dewey" (Deledalle 2002: 48). But Foucault found greater inspiration in Dewey's logical works than 
in its educational ones and he never mentioned having read Democracy and Education. More generally, and beyond the special case of Michel Foucault, it should be noted that Dewey suffered from a strange and persistent silence from philosophers. After the years immediately following the publication of the French translation of Democracy and Education, this silence will persist up until the years 1990s and a progressive renewal of interest in Dewey through the reception of neo-pragmatism and the involvement of a new generation of philosophers such as Jean-Pierre Cometti or Joëlle Zask.

\section{Conclusion: Studying Democracy and Education - A Task Still Before Us}

Focusing on the two main periods during which John Dewey's Democracy and Education has received particular attention brings several observations. First of all, the reception of Dewey's book is always engaged in a movement involving individuals as well as global trends. The individuals who wrote reviews of the book all developed a singular interpretation of it, in coherence with the situation in which their particular outlooks develop. Vocational education emphasized by Julien Fontègne and Max Lazard meets the needs of World War I aftermath as well as the sociological project of developing course choice to fight unemployment and develop child-centered education. Similar statements can be made about André Lalande and the defense of a philosophy of experimentation, Adolphe Ferrière and the pedagogical side of the New Education movement, Gérard Deledalle and the acknowledgment of American philosophy, Georges Cogniot and a Marxist interpretation of educational reform, or Olivier Reboul and the constitution of Philosophy of education as a full field of study. Each one of these reviews raises questions which are central to the understanding of Democracy and Education, concerning the status of philosophy of education, the role of pedagogy and schools in the reform of society, the place granted to experimentation in man's experience of his world, etc.

In so doing, they configure Dewey's reflection as a resource to think problems that were not necessarily and originally his own or those he intended to face with his book. From an epistemological point of view, the emergence of history in the understanding of Dewey's pragmatism represents a wide field of investigation. It suggests as a working hypothesis that an effort of reconstruction needs a prior recontextualization (Garrison 2008). If reading Democracy and Education has something to tell us or to teach us regarding today's problems and issues, it is because it is itself the product of a reflection addressing problems in a given situation, though not limited by it or to it. It may also help us in better understanding the types of discourse we produce, especially those based on the comprehension of one's philosophy. While a third moment of reception is currently going on with the reprinting of Democracy and Education's translation in 2011 and the revival of interest in pragmatist philosophy, especially Dewey's, a retrospective outlook is likely to bring a deeper insight over the specificity and the relevance of our own contributions for the development of Deweyan thought as well as of the analysis it allows us to establish of today's issues. Out of the many lives it already experienced through the past, Democracy and Education still has many more ahead to keep alive a philosophical reflection on the continuously renewed signification of education. 


\section{BIBLIOGRAPHY}

AVANZINI G., (1977), "Hommage à Dewey, à l'occasion du 25e anniversaire de sa disparition," Société Alfred Binet \& Théodore Simon. Art et Techniques pédagogiques 555, 100-1.

BAILEY DE ERMINY Z., (1964), John Dewey, éducateur: une théorie de l'expérience et de la liberté, Unpublished doctoral dissertation, Faculté des Lettres et Sciences Humaines de l'Université de Paris, Paris.

BOURDIEU P., (2000), Pascalian Meditations, transl. Nice R., Cambridge, Polity Press.

COGNIOT G., (1953), "Pour livrer bataille en science et en philosophie, il faut en finir avec l'opportunisme," France nouvelle 381, 6-7.

COGNIOT G., (1976), “Démocratie et éducation,” La pensée 186, 104-11.

DEBEsSE M., (1965), “Préface,” in Deledalle G., La pédagogie de John Dewey, Paris, Éditions du Scarabée.

DELEDALLE G., (1954), Histoire de la philosophie américaine, Paris, PUF.

Deledalle G., (1965), La pédagogie de John Dewey. Philosophie de la continuité, Paris, Éditions du Scarabée.

DELEDAlLE G., (1967), L'idée d'expérience dans la philosophie de John Dewey, Paris, PUF.

DeledAlle G., (1975), “Présentation,” in Dewey J., Démocratie et éducation, Paris, Armand Colin.

DELEDALLE G., (1987), La philosophie américaine, Bruxelles, De Boeck.

DeledAlle G., (1990), “La pédagogie de John Dewey,” in Dewey J., Démocratie et éducation, 2nd ed., Paris, Armand Colin.

DELEDALLE G., (1995), La philosophie peut-elle être américaine?, Paris, Grancher.

DELEDALLE G., (2002), “Michel Foucault. Le tournant tunisien: du structuralisme à l'analyse pragmatique," Les cahiers de Tunisie 182, 45-51.

DELEDALLE G., (2010 [1950]), “1950.10.27 (12309): Gérard Deledalle to John Dewey,” in Hickman L. A., (ed.), The Correspondence of John Dewey, 1871-1952 (I-IV). Electronic edition, Charlottesville, VA, InteLex Corporation.

DEWEY J., (1920), “La valeur éducative de l'enseignement professionnel,” [transl. Lazard M.], Association Française pour la Lutte contre le Chômage et pour l'Organisation du Marché du Travail 38-39, 30-44.

DEWEY J., (1969-1991), The Collected Works, 1882-1953, edited by Boydston J. A., 37 vols., Carbondale and Edwardsville, IL, Southern Illinois University Press.

DEWEY J., (1975), Démocratie et éducation, transl. Deledalle G., Paris, PUF.

DURKHeIM É., (1956 [1922]), Education and Sociology, transl. Fox S. D., New York, The Free Press.

FERRIÈRE A., (1920), Transformons l'école. Appel aux parents et aux autorités, Bâle, Bureau international des écoles nouvelles. 
FERRIÈRE A., (1927), “La Démocratie et l'Éducation selon J. Dewey,” L'Éducation, 18, 5, 274-80.

FERRIÈRE A., (2010 [1914]), “1914.02.05 (03279): Adolphe Ferrière to John Dewey,” in Hickman L. A., (ed.), The Correspondence of John Dewey, 1871-1952 (I-IV). Electronic edition, Charlottesville, VA, InteLex Corporation.

FONTÈGNE J., (1923), Manualisme et éducation, Paris, Eyrolles.

FRELAT-KAHN B., (2013), Pragmatisme et éducation. James, Dewey, Rorty, Paris, Vrin.

GARRISON J., (ed.), (2008), Reconstructing Democracy, Recontextualizing Dewey. Pragmatism and Interactive Constructivism in the Twenty-first Century, Albany, NY, State University of New York Press.

GIREL M., (2014), “Peirce's Reception in France: Just a Beginning," European Journal of Pragmatism and American Philosophy, 6, 1, 15-23.

HAMELINE D., (1995), "L'anonyme et le patronyme, portraits et figures de l'Éducation nouvelle," in Hameline D., Helmchen J., \& Oelkers J., (eds.), L'éducation nouvelle et les enjeux de son histoire. Actes du colloque international des Archives Institut Jean-Jacques Rousseau, Berne, Peter Lang, 131-60.

KOHLER A., (1917), “John Dewey. Démocratie et éducation: introduction à la philosophie de l'éducation," L'Éducation, 9, 4, 453-4.

LALANDE A., (1920), “Éducation et démocratie," Revue philosophique de la France et de l'étranger 89, 277-300.

LALANDE A., (1929), Les théories de l'induction et de l'expérimentation, Paris, Boivin \& Cie.

LALANDE A., (1950), "Reflections of a French Philosopher on the Preceding American Essays," in Farber M., (ed.), Philosophic Thought in France and the United States: Essays Representing Major Trends in Contemporary French and American Philosophy, Buffalo, NY, University of Buffalo Publications in Philosophy.

LALANDE A., (2006), Vocabulaire technique et critique de la philosophie, 2nd ed., Paris, PUF.

LAZARD M., (1920), "Note sur la Philosophie de l'Éducation," Association Française pour la Lutte contre le Chômage et pour l'Organisation du Marché du Travail 38-39, 28-30.

ou T.-C., (1958), La doctrine pédagogique de John Dewey, 2nd ed., Paris, Vrin.

PUDAL R., (2007), Les réceptions du pragmatisme en France (1890-2007). Histoires et enjeux, unpublished doctoral dissertation, École des Hautes Études en Sciences Sociales, Paris.

REBoul O., (1970), “John Dewey, pédagogue de l'homme unidimensionnel?,” Critique 279-280, 759-73.

REBoul O., (1978), "Démocratie et éducation, par John Dewey," Revue de Métaphysique et de Morale, $83,3,427-28$.

REBOUl O., (2004 [1971]), La philosophie de l'éducation, 9th ed., Paris, PUF.

RENIER S., (2012), “John Dewey et l'Éducation nouvelle en France (1930-1970)," in Gutierrez L., Besse L., \& Prost A., (eds.), Réformer l'école. L'apport de l'Éducation nouvelle (1930-1970), Grenoble, Presses Universitaires de Grenoble.

RENIER S., (2013), "Un siècle de pragmatisme. L'influence de John Dewey sur la pédagogie française (1913-2013)," Rassegna di Pedagogia, 71, 1-2, 27-54. 
RENIER S., (2014), “Comment nous traduisons: la réception de l'œuvre de John Dewey par Ovide Decroly," La pensée et les hommes 92, 273-94.

RENIER S., (forthcoming), “Reconstructing Dewey, Rethinking Education. The Legacy of John Dewey's Educational Thought and the Development of the Sciences De l'Éducation in France since 1967," Mediterranean Journal of Educational Studies.

SCHNEIDER J.-H., (2000), “John Dewey in France,” Studies in Philosophy and Education, 19, 1, 69-82.

SChUltenover D. G., (ed.), (2009), The Reception of Pragmatism in France \& the Rise of Roman Catholic Modernism, 1890-1914, Washington, D.C., The Catholic University of America Press.

TOAN D.V., (1965), L'éducation sociale d'après Platon et Dewey. Étude critique et esquisse d'une solution aux problèmes de l'éducation dans une démocratie, unpublished doctoral dissertation, Faculté des Lettres et Sciences Humaines de l'Université de Paris, Paris.

TRÖHLER D., (2009), “Langue as Homeland: The Genevan Reception of Pragmatism," in Popkewitz T. S., (ed.), Inventing the Modern Self and John Dewey. Modernities and the Traveling of Pragmatism in Education, New York, Palgrave Macmillan.

[Unknown author], (1976), Review of the book Democracy and Education. An Introduction to the Philosophy of Education, by J. Dewey, Bulletin critique du livre français 367, 1289.

\section{NOTES}

1. Max Lazard (1875-1953) was a French banker and intellectual, who mainly dedicated his life to fighting unemployment. Though not a direct student of Durkheim, he was greatly influenced by the development of his sociological thought in his own works on the function of labor in the social organization. He was the founder and president of the Association Française pour la Lutte contre le Chômage et pour l'Organisation du Marché du Travail, and of its Bulletin in which Dewey's translation and review appeared.

2. Julien Fontègne (1879-1944) was a French school inspector of technical education. He was a pioneer of the development of vocational choice and education, and participated to the foundation of the Institut National d'Orientation Professionnelle (National Institute for Vocational Choice) along with Henri Piéron and Henri Laugier.

3. As he defined in 1911, in "Education: Its Nature and Its Role": "Education is the influence exercised by adult generations on those that are not yet ready for social life. Its object is to arouse and to develop in the child a certain number of physical, intellectual and moral states which are demanded of him by both the political society as a whole and the special milieu for which he is specifically destined" (Durkheim 1956: 71).

4. Albert Kohler (1873-?) was a Swiss pastor and theologian. He achieved a doctoral thesis on Le Bonheur dans l'enseignement de Jésus (Happiness in Jesus' teaching) in 1897.

5. The School and the Child is not a genuine book written by Dewey, but a volume edited by J. J. Findlay in London (publisher: Blackie \& Son Limited) in 1906. It gathers four essays previously and separately published by Dewey: "Interest as Related to (the training of the) Will," Second Supplement to the Herbart Yearbook for 1895, Bloomington, National Herbart Society, 1896, 209-255 (EW 5: 111-50); The Child and the Curriculum, Chicago, University of Chicago Press, coll. "University of Chicago Contributions to Education," 1902 (MW 2: 271-91); "The Aim of History in Elementary Education," The Elementary School Record 8, November 1900, 199-203 (MW1: 104-9); "Ethical Principles Underlying Education," Third Yearbook, Chicago, National Herbart Society, 1897, 7-34 (EW 5: 54-83). References to John Dewey's published works are to the critical edition, The Collected Works of John Dewey, 1882-1953, edited by Boydston J. A., Carbondale and 
Edwardsville, Southern Illinois University Press, 1967-1991, and published in three series as The Early Works 1882-1899 [EW], The Middle Works 1899-1924 [MW], and The Later Works 1925-1953 [LW].

6. Even by Dewey scholars such as Ou Tsuin-Chen or Gérard Deledalle.

7. André Lalande (1867-1963) was a French philosopher. He is mostly renowned for his Vocabulaire technique et critique de la philosophie (Technical and Critical Vocabulary of Philosophy), which he constituted between 1902 and 1923 and which was finally published as two volumes in 1926.

8. Ludovic Zoretti (1880-1948) was a French mathematician. He wrote a few works on education in the wake of his commitment as a unionist toward popular education.

9. One of the most striking examples of that oblivion is to be found in the volume edited in 1950 under the title Philosophic Thought in France and in the United States. Lalande wrote the concluding chapter "Reflections of a French Philosopher on the Preceding American Essays," in which he does not approach Dewey, whereas the preceding essays did (Lalande 1950).

10. Bureau International des Écoles Nouvelles.

11. Ligue Internationale pour l'Éducation Nouvelle.

12. As an illustration of that policy, one may recall that it is that same journal which published the full translations of The School and Society's first three chapters between 1909 and 1914.

13. An English translation was published in 1928 by John Day Co, thanks to F. Dean Moore and F. C. Wooton.

14. The same parallel can be found in Ferrière's books. As soon as 1920, and without any connection with Democracy and Education, he already mentioned "the vast movement in favor of the 'Activity School' initiated in the United States by John Dewey" (Ferrière 1920: 45).

15. Such was already the case with Ovide Decroly, when he translated How We Think in 1925 (Renier, 2014).

16. Some relations do exist, however, between Bourdieu and Dewey as show the quotes of the latter made by the former in its Pascalian Meditations in order to justify theoretically his critique of the scholastic reason (Bourdieu 2000: 31 ).

17. Though published in 1965 as a separate volume, this book consists in a new edition of a series of five papers Deledalle published in between October 1950 and March 1951 in the journal Pédagogie (Pedagogy).

18. We shall not here discuss the choices made by Deledalle to translate some specific words or phrases.

19. On the link between Dewey's reception and the foundation of Educational Sciences in France, see: Renier forthcoming.

20. The original project of Deledalle's two doctoral dissertations was precisely to study each one of these two concepts in Dewey's philosophy (Deledalle 2010). He also considered to translate Experience and Nature, but finally turned to Logic - The Theory of Inquiry which he presented instead of the second study on continuity.

21. We do not take here into consideration the review published in the 367th issue of the Bulletin critique du livre français, in July 1976, because of its shortness and of its character as a résumé for librarians.

22. Georges Cogniot (1901-1978) was a French politician and philosopher. He quickly became a member of the French Communist Party and a leader of its intellectual branch. He founded the Marxist journal La pensée, in which he published a great number of articles, especially on educational issues.

23. The French adjective pédagogiste refers to the term pédagogisme, which pejoratively designates all those who are believed to place pedagogy before every other means or goals, on the base of a faith placed on the influence of the educational work done in classrooms that would be more powerful than any other reform.

24. For a more detailed account of that campaign, see Renier 2013. 
25. Guy Avanzini (1929-) is currently professor emeritus at the University of Lyon II (France). He's a renowned specialist of the history of educational ideas.

26. Experiments that he himself condemned or warned us about, four decades earlier, as in "Progressive Education and the Science of Education."

27. Maurice Debesse already mentioned in the preface he wrote to Deledalle's La pédagogie de John Dewey (John Dewey's Pedagogy) in 1965 that when he exposed the conclusion of Experience and Education to his colleagues or his student, "they welcomed it without pleasure, as if it were a backing down from their apostle" (Debesse 1965: 11).

28. Olivier Reboul (1925-1992) was a French philosopher and professor emeritus of Educational Sciences at the University of Strasbourg. He was a renowned specialist of French philosopher Alain and greatly contributed to the development of philosophy of education in France.

29. As a collective review - which is a particularity of this journal - along with Deledalle's books on The Idea of Experience in John Dewey's Philosophy and John Dewey's Pedagogy, and with the new printing of the French translation of The School and the Child.

30. See, for instance, the tribute published in the daily newspaper Le Monde by Deledalle, in its edition of January the 8th 1993, after Reboul's death.

31. See the numerous parallels he draws between them in his book L'éducation selon Alain (Education According to Alain), published in 1974.

\section{ABSTRACTS}

Originally published in 1916, John Dewey's seminal book Democracy and Education was not translated into French until 1975, thanks to the work accomplished by Gérard Deledalle. Welcomed by a relative indifference on the part of French philosophers, the book only received attention from a few intellectuals, working in the field of educational sciences. But this has not always been the case. The main purpose of this paper is so to study the various ways according to which Dewey's work has been read and used over the last century. Based on a comprehensive review of French literature concerning Dewey, it underlines two mains moments proposing divergent interpretations and uses of his ideas, with the decade following its original publication; and, its translation into French. The relevance and the topicality of such a historical work appears to be all the more important as the beginning of the 21st century is marked by a rediscovery of Deweyan thought by the French audience, with the noticeable reprinting of Democracy and Education. In so doing, we shall thus point out the moving and transactional character of a book still to be read, pragmatically.

\section{AUTHOR}

\section{SAMUEL RENIER}

Université François-Rabelais de Tours (France) - Équipe émergente "Éducation, Éthique et Santé" samuel.renier[at]univ-tours.fr 